Article

\title{
Relevance and Benefits of Urban Water Reuse in Tourist Areas
}

Valentina Lazarova $^{1, *}$, Vincent Sturny ${ }^{2}$ and Gaston Tong Sang ${ }^{3}$

1 Suez-Environment, 38 rue du président Wilson, Le Pecq 78230, France

2 Société Polynésienne de l'Eau et de l'Assainissement, Papeete-Tahiti 98713, French Polynesia

3 Municipality of Bora Bora, Vaitape, Bora Bora 98730, French Polynesia

* Author to whom correspondence should be addressed; E-Mail: valentina.lazarova@suez-env.com; Tel.: +33-1-3480-2251; Fax: +33-1-3480-3838.

Received: 30 December 2011; in revised form: 7 January 2012 / Accepted: 7 January 2012 /

Published: 31 January 2012

\begin{abstract}
Urban water reuse is one of the most rapidly growing water reuse applications worldwide and one of the major elements of the sustainable management of urban water cycle. Because of the high probability of direct contact between consumers and recycled water, many technical and regulatory challenges have to be overcome in order to minimize health risks at affordable cost. This paper illustrates the keys to success of one of the first urban water reuse projects in the island Bora Bora, French Polynesia. Special emphasis is given on the reliability of operation of the membrane tertiary treatment, economic viability in terms of pricing of recycled water and operating costs, as well as on the benefits of water reuse for the sustainable development of tourist areas.
\end{abstract}

Keywords: dual network; integrated water resource management; cost benefit analysis; sustainable development; urban water reuse

\section{Introduction}

Urban water reuse is developing rapidly and is becoming a key element of the integrated water resource management policy of large cities. The most frequent uses are the irrigation of green areas (parks, golf courses, sports fields, greenbelts), urban developments (waterfalls, fountains, lakes), in-building uses for air conditioning and/or toilet flushing, road and street cleaning, car washing and fire fighting. Such reuse schemes are very often associated with ornamental or recreational water reuse features such as ponds, fountains, wetlands. 
Japan is the leading country in the field of urban water recycling with a supply of $180 \mathrm{Mm}^{3} / \mathrm{yr}$ (million cubic meters per year), mostly for urban purposes, $18 \%$ for toilet flushing and $50.4 \%$ for environmental enhancement [1]. The average daily volume of recycled water for toilet flushing is $103,500 \mathrm{~m}^{3} / \mathrm{d}$. The major part, $85 \%$ of this volume, is produced on-site and used in 1,058 individual buildings and block-wide water recycling systems.

One of the first and largest projects for urban reuse in the world was implemented in St. Petersburg (FL, USA), in the late 1970s [2] (pp. 1453-1459). Over 136,000 $\mathrm{m}^{3} / \mathrm{d}$ recycled water are distributed to over 10,400 consumers by means of $470 \mathrm{~km}$ dual distribution system for irrigation, toilet flushing, fire protection, filling of swimming pools, decorative pools and ponds, washing purposes, etc. Significant economic benefits have been derived from this water reuse system. An example is a cost saving of about 30 million US dollars from the postponement of the expansion of drinking water treatment and pumping. With the extension of the water reuse program, St. Petersburg has become the first major municipality in the United States to achieve zero discharge of wastewater effluents.

The Irvine Ranch Water District in California successfully implemented urban water reuse in the middle 1980s, thus expanding agricultural reuse that had been initiated in 1967. In 2006, 90\% of landscape irrigation was supplied with recycled water by means of a $483 \mathrm{~km}$ dual distribution system, 13 storage reservoirs and 15 pumping stations [2] (pp. 915-918). Currently, up to $80 \%$ of the water demand of high-rise commercial buildings is met with recycled water.

During the last decade, several urban water reuse schemes have been implemented in Australia. The first example of urban water reuse was implemented in 2001 in Rouse Hill near Sydney, serving 12,000 private properties with some $34 \mathrm{~km}$ dual pipes and a perspective of extension for up to 35,000 homes $[3,4]$. High-quality recycled water is produced for toilet flushing and landscape irrigation by means of tertiary treatments using ozonation, microfiltration and chlorination. The primary benefit reported was a reduction of the drinking water demand by about $35 \%$. This lesson encouraged Sydney Water to adopt an ambitious water reuse program, which aims to have 25 more water recycling schemes in place by 2015, supplying $12 \%$ of Sydney's water needs. In 2009, another large dual reticulation scheme was online in Pimpama-Coomera, Queensland, serving up to 45,000 homes for toilet flushing and outdoor uses [5]. A detailed investigation of end use patterns demonstrated that peak demand on potable water was significantly reduced (recycled water accounts for $32.2 \%$ of total daily consumption, with irrigation being $15.7 \%$ ).

Golf course irrigation is the most rapidly growing water reuse application in South Europe, as for example in France, Portugal, and Spain. Spain is the water reuse leader in Europe with an annual recycled water volume of $408 \mathrm{Mm}^{3} / \mathrm{yr}$, which growth is favored by a new policy requirement to use only recycled water for golf course irrigation. For example, $22 \%$ of the treated wastewater in Costa Brava was reused in 2010 which represents a recycled volume of $6.7 \mathrm{Mm}^{3} / \mathrm{yr}$. The major uses are for golf course irrigation ( $25 \%$ of the total recycled water volume) and environmental enhancement [6].

To facilitate communication and public acceptance of water reuse, it is very important to understand and use the appropriate terminology. Water reuse is the most commonly used term for the beneficial use of treated wastewater. Treated wastewater suitable for a given reuse application is often called reclaimed or recycled water. Because the public is widely engaged in recycling paper, glass, plastics and other household wastes and clearly understands what the word recycling means, water recycling is the preferred term in several recent regulations. According to the Shorter Oxford English Dictionary 
(6th Edition 2007) reuse and recycling are synonyms. Consequently, water reuse and water recycling are used in this paper as synonyms to indicate the use of properly treated wastewater for beneficial purposes. In some countries, other specific terms are used to indicate recycled water, for example "industrial" water in France, "NeWater" in Singapore, "Eco-water" in the Netherlands, etc.

The feed back from the operation of urban water recycling schemes worldwide demonstrates that the main advantage of recycled water is that it is "drought-proof", enabling to save natural freshwater for domestic use and reduce the peak drinking water demand. As a rule, the public attitude is positive to the use of recycled water for non-potable urban uses such as landscape irrigation and toilet flushing [7]. Users expect the operators of such systems to maintain suitable quality and run the systems safely. The main constraints of the urban water reuse are the high cost of dual reticulation systems and the needs of extensive maintenance, cross-connection control and water quality monitoring.

The energy requirement of water recycling depends on the water quality and the required additional treatment. The specific energy consumption of conventional tertiary treatment of secondary effluents (coagulation/flocculation, rapid sand filtration, UV disinfection) is relatively low and similar to freshwater energy costs, typically 0.15 to $0.3 \mathrm{kWh} / \mathrm{m}^{3}$. Membrane processes (MF, UF, NF) require much more energy, 0.35 to $0.65 \mathrm{kWh} / \mathrm{m}^{3}$. The implementation of reverse osmosis and advanced oxidation, for the removal of organic micropollutants and desalination, leads to an additional two fold increase of energy requirements up to $1.1-2.0 \mathrm{kWh} / \mathrm{m}^{3}$, which still remains almost $50 \%$ below the typical energy costs of seawater desalination. In addition to the energy requirements for treatment, water reuse projects should consider distribution and transportation costs that can be sometimes similar and even higher than treatment costs.

These constraints, combined with the lack of adequate regulations, impede the implementation of urban water reuse projects. In France, for example, the very restrictive new regulation adopted in 2010 does not allow sprinkler irrigation and hinders the development of water reuse projects for golf course and landscape irrigation [8]. In fact, public health issues are a major concern of responsible institutions in regions where water reuse is not yet widely applied, such Northern Europe.

In this context, the main objective of this paper is to present and discuss the keys to success of one of the first urban water reuse projects in France and the French territories (the island of Bora Bora, French Polynesia). Special emphasis is given to the technical challenges for production of high-quality recycled water, the high reliability of operation and supply, the cost-benefit analysis and the role of water reuse in integrated water resource management.

\section{Materials and Methods}

The treatment efficiency and the operating cost of the full-scale membrane tertiary treatment have been monitored for three years. Ultrafiltration organic submerged membranes Zenon (ZeeWeed 500) have been chosen to polish a part of the secondary effluent and implemented in 2005 at the wastewater treatment plant of Povai. The main objective of this innovative tertiary treatment was to produce high-quality totally disinfected recycled water for unrestricted reuse purposes. The initial treatment capacity of $300 \mathrm{~m}^{3} / \mathrm{d}$ was expanded to $500 \mathrm{~m}^{3} / \mathrm{d}$ in 2008 . The down-stream treatment, with a wet daily flow of $6,250 \mathrm{~m}^{3} / \mathrm{d}$, consists in conventional activated sludge designed for carbon and nitrogen removal. 
Water quality parameters were monitored according to Standard Methods. Physico-chemical parameters ware analyzed in $24 \mathrm{~h}$ composite samples. Sampling frequency was daily during the start-up period and monthly during routine operation. For the microbiological analysis, grab samples were taken at the outlets of the ultrafiltration and the storage reservoir into $200 \mathrm{~mL}$ sterile glass bottles, kept at $4{ }^{\circ} \mathrm{C}$ until use, and thus before 24 h. E. coli and enterocci numerations were conducted with the microplate technique according to NF EN ISO 9308-1] and NF EN ISO 7899-2 standardized method. During the start-up of ultrafiltration, other microorganisms were also monitored such as total coliforms, spores of Clostridium perfringens according to French AFNOR V59-107 standardized method and Salmonella spp. according to European norm EN 12824:1997.

In order to ensure public acceptance of the water reuse scheme in Bora Bora, a proven and recommended approach of community consultation has been used [9]. The methodology applied consisted in the organization of public meetings and forums with broad interest groups (local populations, local entities, municipalities, water utilities, legislative officers), consultations with interest groups to validate proposed technologies, treatment performance, associated risks and benefits, as well as an active collaboration with local media.

\section{Results and Discussion}

\subsection{Driving Factors of Water Reuse and Its Role in Integrated Water Resource Management}

Since 1998, the island of Bora Bora regularly has to face water shortages, due primarily to decreasing rainfall and frequent droughts combined with hotel development and population growth. As a result, severe water shortage has been observed with periodic interruptions of water supply. In 2000, to ensure a reliable water supply $24 / 24 \mathrm{~h}$, the island was equipped with alternative resources such as desalination and water reuse.

Consequently, a municipal policy of sustainable development was implemented in Bora Bora, known as the "Pearl of the Pacific" and globally renowned for the beauty of its lagoon. This policy found support in an intense willingness of the elected representatives for a meticulous respect of the environment, preservation of the island's charm and water resources, as well as building design adapted to landscape and local tradition. The concept of sustainable development of the municipality of Bora Bora is a model of economic development and aims at a conciliation of the following elements (Figure 1):

1. Economic development with the creation of wealth through tourism related activities.

2. Sustainable management of natural resources and protection of the environment, especially water resources and the ecosystem of the lagoon, rich but fragile and vulnerable.

3. Social development aiming social wellbeing and full employment. 
Figure 1. The concept of sustainable development of the municipality of Bora Bora.

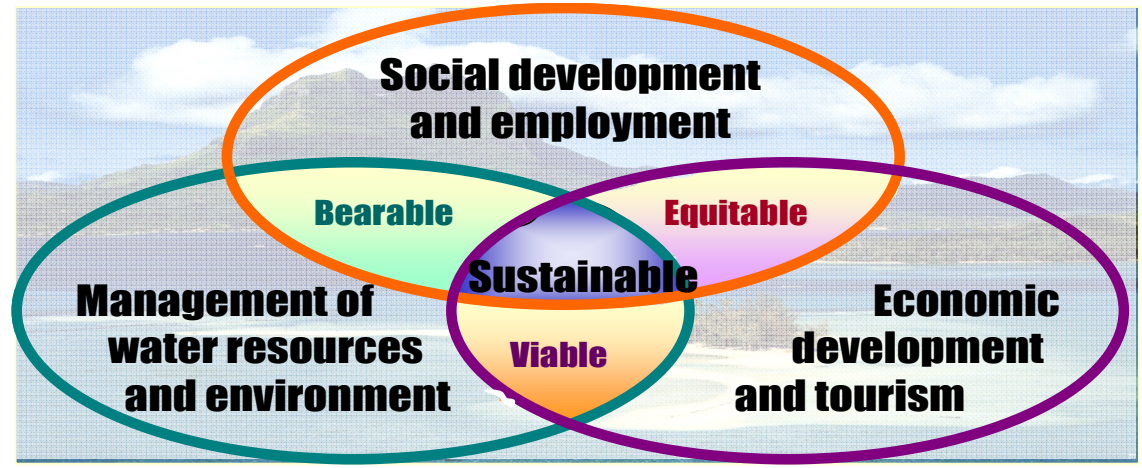

A very important element in this policy is the management of water resources. The freshwater resources of the island are not sufficient to provide for the resident population (8,000 inhabitants) and 200,000 tourists a year. Following a growth in water demand and increasingly more severe dry seasons, the production capacity of drinking water was due to be increased several times, with the introduction of alternative resources such as desalination of seawater and water reuse (Figure 2).

Figure 2. Main stages of development of water production and supply.

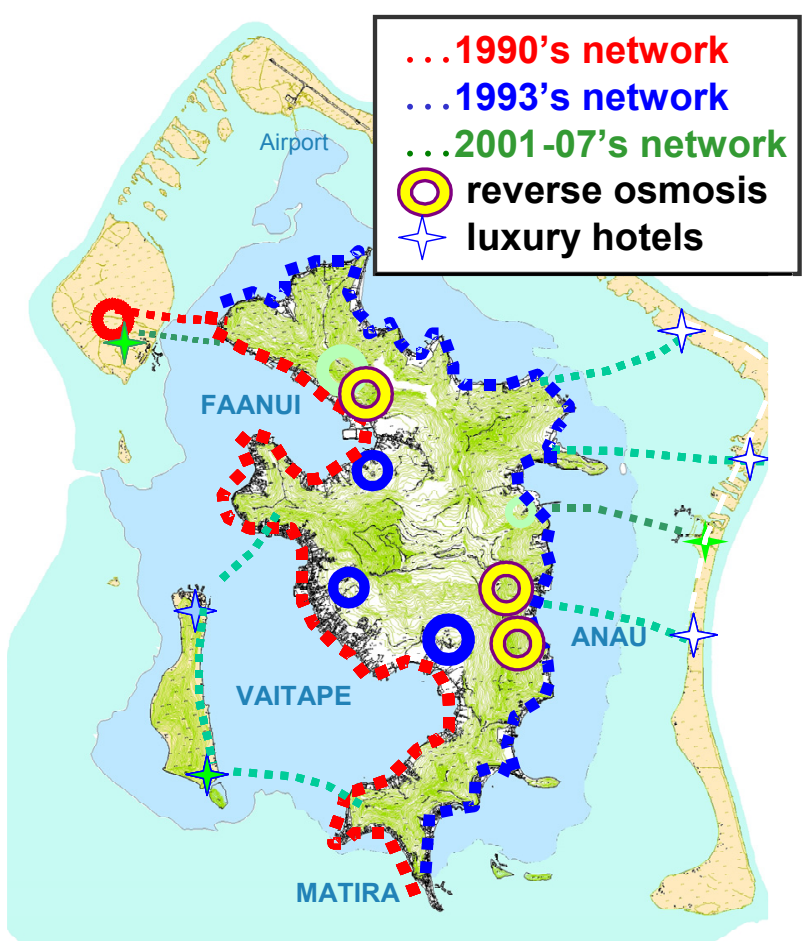

The major steps in improving the island's water supply were:

- 1990: limited resources $\left(1,200 \mathrm{~m}^{3} / \mathrm{d}\right)$, discontinuous service, partial coverage, non-potable water quality, and creation of a public-private partnership.

- 1993: introduction of new boreholes $\left(3,600 \mathrm{~m}^{3} / \mathrm{d}\right)$, extension of the network to the whole island, insured service 24/24h, drinking water in accordance with European standards.

- 2000: water deficit related to the effects of drought and the Niňa, construction of the first desalination plant with 3 units of reverse osmosis with a production capacity of $350 \mathrm{~m}^{3} / \mathrm{d}$ each. 
- 2005: construction of a new desalination plant of $1,000 \mathrm{~m}^{3} / \mathrm{d}$ and water recycling by ultrafiltration with a design capacity of $300 \mathrm{~m}^{3} / \mathrm{d}$.

- 2007: construction of the third desalination plant of $1,000 \mathrm{~m}^{3} / \mathrm{d}$. The latter two desalination facilities benefit from technological advance ensuring a global saving of $40 \%$ of the energy consumed by the first desalination plant.

- 2008: extension of the capacity of water recycling by ultrafiltration to $500 \mathrm{~m}^{3} / \mathrm{d}$.

- 2010: extension of the dual distribution network and construction of a new storage reservoir.

It is important to emphasize that in the context of sustainable development, water resource management should include not only reliable water supply, but also adequate sanitation services of collection and treatment of wastewater. In the case of Bora Bora, the construction of hotels and housing rapidly upset the island's way of life: uncontrolled sewage discharge led to the eutrophication of the lagoon and the beautiful white-sand beaches started to be covered by green algae. It was under the leadership of its elected officials that the Island was then attached to adopt all possible means to achieve efficient sanitation services.

All raw sewage of the island is collected and transported in a pressurized network by means of 70 pumping stations. It is then treated in two wastewater treatment plants (one on the north side and the other on the south side of the island). The first water reuse scheme was build on the basis of a natural tertiary treatment in a maturation pond. However, the quality of this recycled water was not approved by the local health authorities for spray irrigation. Moreover, recurrent odor problems and bacteria regrowth (in particular sulfur-reducing bacteria) in the distribution network associated to the relatively high cost of recycled water led the consumers, in particular the luxury hotels, to limit their recycled water demand.

In 2005, the water reuse project was upgraded to the production of high quality recycled water for unrestricted non-potable urban uses. Over the years, this project has expanded, including diversification of water reuse applications and design of a new project for indirect potable reuse. The recycled water distribution network has been extended to completely cover the demand of non-potable water of all luxury hotels. The quality of recycled water is rigorously monitored by the Territorial Public Health and Hygiene Department. The good quality of basic wastewater treatment and the reduced wastewater discharge have had a pronounced effect on the natural habitat, the algae development was stopped, the white-sand beaches have been restored to the original beauty so treasured by tourists and photographers around the world.

Therefore, the strong willingness of the local decision makers for the protection and restoration of environment was the first driver for implementing sanitation, which in turn has made possible water reuse and the resulting additional environmental enhancement. In addition to the protection of environment and water reuse, the other measures adopted by the municipality in the frame of their program on sustainable development is the use of geothermal energy for cooling, use of solar energy, preservation of local tradition and employment, as well as social and economic development taking advantage of revenues generated by tourist activity. Thus, Bora Bora was the only municipality of French Polynesia, which has been awarded the "Blue Flag of Europe" and has been able to preserve this award for ten consecutive years. This categorization is highly prized by foreign visitors, mostly from northern Europe, who tend to select their vacation spot based on environmental criteria. 
In summary, the most important driving forces for the implementation of water reuse in Bora Bora were water stress (impacts of climate change and frequent droughts) and the increasing water demand of tourist activities. The strong community engagement with close cooperation between stakeholders was the major factor for the recognition of the benefits of water reuse and its important role in integrated water resource management of this isolated tourist island.

\subsection{Water Quality and Reliability of the Water Recycling Scheme}

The new recycling scheme, implemented in 2005 in the wastewater treatment plant of Povai, included an advanced membrane treatment by ultrafiltration, using the hollow fiber submerged membranes Zenon manufactured by GE Water (Figure 3). The existing maturation pond was upgraded for storage of storm water. Recycled water is stored in covered reservoir and pumped into the industrial (non-potable) water distribution network after chlorination in order to maintain $0.5 \mathrm{mg} / \mathrm{L}$ chlorine residual. The choice of ultrafiltration as tertiary treatment was driven by the willingness to produce recycled water of high quality that is completely disinfected. The ultrafiltration membranes have small pore size of $0.035 \mu \mathrm{m}$, which represents an effective physical barrier for all microorganisms and pathogens, including protozoa, cysts, bacteria and viruses.

Figure 3. Schematic flow diagram of wastewater treatment and recycling of the Povai wastewater treatment and recycling plant.

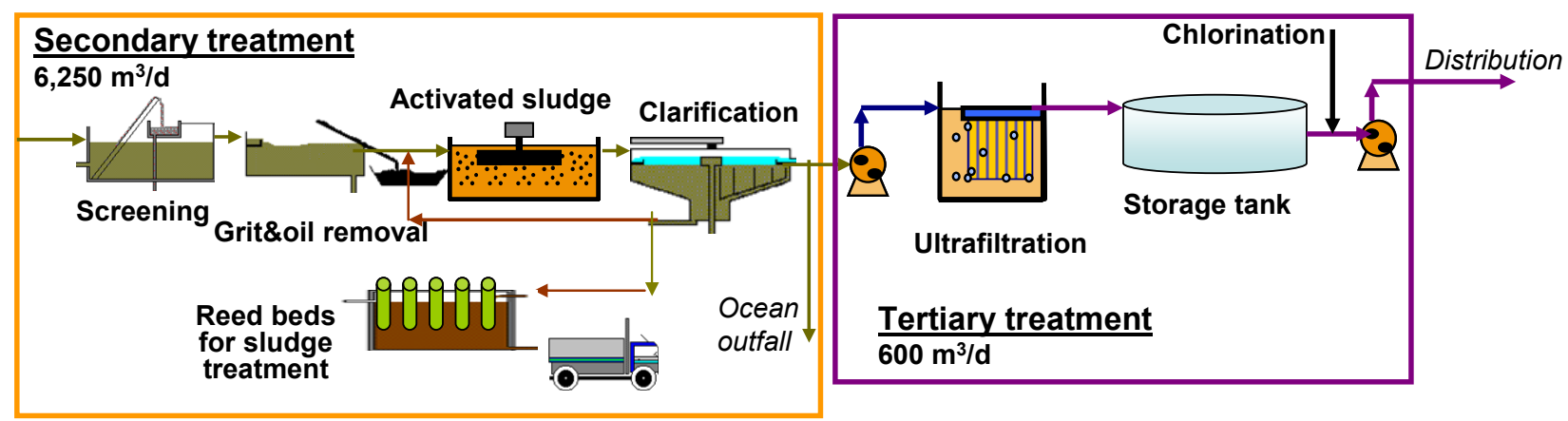

The excess sludge is treated and recycled by rhizocomposting in reed beds. The compost obtained ( $>1200 \mathrm{~m}^{3} /$ year) is reused to fertilize the poor coral based soils of hotel's landscapes, public areas and private gardens.

Table 1 illustrates the routine monitoring of wastewater quality (raw sewage, secondary effluent and recycled water) for one year. Despite the high variations of raw sewage characteristics, tertiary ultrafiltration consistently produced an effluent with a very good quality, almost free of suspended solids and with a very low content of organic carbon. The produced recycled water was almost totally disinfected. The detailed microbiological monitoring during the first 6-months of operation demonstrated the good removal of all monitored indicators (E.coli, enterococci, total coliforms, Clostridium spores) and pathogens (Salmonella spp.). Salmonella spp. were not detected in any sample of recycled water. As a rule, microbial indicators were always below detection limits in all samples from the inlets of membranes and the storage reservoir. 
Table 1. Routine water quality control of the wastewater treatment and recycling facility of Povai for the year 2009.

\begin{tabular}{|c|c|c|c|c|}
\hline \multirow{2}{*}{ Parameter } & \multirow{2}{*}{$\begin{array}{c}\text { Raw } \\
\text { sewage }\end{array}$} & \multirow{2}{*}{$\begin{array}{c}\text { Permit } \\
\text { value }\end{array}$} & \multicolumn{2}{|c|}{ Treated water * } \\
\hline & & & Secondary effluents & Distribution system \\
\hline E.coli $/ 100 \mathrm{~mL}$ & $10^{5}-10^{7}$ & $0 / 100 \mathrm{~mL}$ & $38-4335$ & ND \\
\hline Enterococci/100 mL & NA & $0 / 100 \mathrm{~mL}$ & $38-100$ & ND \\
\hline $\mathrm{COD} \mathrm{mg} / \mathrm{L}$ & $270-850$ & $40 \mathrm{mg} / \mathrm{L}$ & $16-54$ & $<5-18$ \\
\hline $\mathrm{BOD}_{5} \mathrm{mg} / \mathrm{L}$ & $200-560$ & $20 \mathrm{mg} / \mathrm{L}$ & $<5-20$ & $<5$ \\
\hline $\mathrm{TSS} \mathrm{mg} / \mathrm{L}$ & $110-280$ & $20 \mathrm{mg} / \mathrm{L}$ & $<5-23$ & $<5-10$ \\
\hline $\mathrm{N}_{\text {tot }} \mathrm{mg} / \mathrm{L}$ & $30-70$ & $20 \mathrm{mg} / \mathrm{L}$ & $4-23$ & $2-20$ \\
\hline $\mathrm{P}_{\mathrm{tot}} \mathrm{mg} / \mathrm{L}$ & $4.1-8.1$ & - & $1.4-5.6$ & $1.1-4.5$ \\
\hline
\end{tabular}

* Limits of variations (12 monthly composite samples, excluding E.coli and Enterococci that was monitored in grab samples), ND: not detected.

During the 5-year operation of the submerged UF membranes, only two samples at the inlet of the ultrafiltration were contaminated with fecal coliforms (E.coli repectively 64 and $100 \mathrm{MPN} / 100 \mathrm{~mL}$ ) and Clostridium spores (respectively 20 and $60 \mathrm{UFC} / 20 \mathrm{~mL}$ ). The additional chlorination was able to inactivate the residual E.coli to concentration below $10 / 100 \mathrm{~mL}$, but 7 to $10 \mathrm{UFC} / 20 \mathrm{~mL}$ of Clostridium spores still remained in the recycled water.

The poor microbiological quality was due to operational failures of valve leakage and overflow of unfiltered secondary effluent. To improve the reliability of operation of the ultrafiltration, the treatment plant was upgraded to not allow any by-pass of unfiltered water or external contamination of the permeate. An on-line turbidity measurement was recommended as an efficient measure to control any valve leakages or breaks of membrane fibbers.

The analysis of agronomic parameters, shown in Table 2, indicates slight to moderate restriction on the use of this recycled water for irrigation [10]. Sodium is the dominant cation with a concentration of $176 \mathrm{mg} / \mathrm{L}$ resulting on a relatively high sodicity with a sodium adsorption ratio, SAR of 4.9.

Table 2. Analysis of selected water quality parameters in the recycled water.

\begin{tabular}{lll}
\hline Parameter & Analytical method & Measured value \\
\hline General parameters & & \\
Temperature & - & $21.5^{\circ} \mathrm{C}$ \\
Conductivity & NF EN 27888 & $1,397 \mu \mathrm{S} / \mathrm{cm}$ \\
Color & NF EN ISO 788-Sect 4 & $30 \mathrm{mg} / \mathrm{L} \mathrm{de} \mathrm{Pt}$ \\
$\mathrm{pH}$ & NF T 90-008 & 8.05 \\
Turbidity & NF EN ISO 7027 & $<0.1 \mathrm{NTU}$ \\
Permanganate index & NF EN ISO 8467 & $4.15 \mathrm{mg} \mathrm{O} / \mathrm{L}$ \\
TDS, 180 & NF T 90-029 & $752 \mathrm{mg} / \mathrm{L}$ \\
Alkalinity & NF EN ISO 9963-1 & $18.3^{\circ} \mathrm{F}$ \\
Bicarbonates & ISO 5813 & $223 \mathrm{mg} / \mathrm{L}$ \\
Dissolved oxygen & & $9.9 \mathrm{mg} \mathrm{O} \mathrm{O}_{2} / \mathrm{L}$ \\
\hline
\end{tabular}


Table 2. Cont.

\begin{tabular}{lll}
\hline Parameter & Analytical method & Measured value \\
\hline Ionic chromatography & & $271 \mathrm{mg} / \mathrm{L}$ \\
Chloride & & $0.14 \mathrm{mg} / \mathrm{L}$ \\
Fluoride & NF EN ISO 10304-1 & $24.7 \mathrm{mg} / \mathrm{L}$ \\
Nitrates & & $56 \mathrm{mg} / \mathrm{L}$ \\
Sulfate & & \\
\hline Molecular adsorption & NF T 90 015-2 & $0.65 \mathrm{mg} / \mathrm{L}$ \\
Ammonia & NF EN ISO 6878 & $3.65 \mathrm{mg} / \mathrm{L}$ \\
Total phosphorus & NF T 90-007 & $18 \mathrm{mg} / \mathrm{L}$ \\
Silicates & & \\
\hline Atomic absorption & NF EN ISO 15586 & $37.2 \mu \mathrm{g} / \mathrm{L}$ \\
Aluminum & NF ISO 7980 & $<0.5 \mu \mathrm{g} / \mathrm{L}$ \\
Cadmium & FD T 90-112 & $42.4 \mathrm{mg} / \mathrm{L}$ \\
Calcium & NF EN ISO 7980 & $<1 \mathrm{mg} / \mathrm{L}$ \\
Copper & NF EN ISO 15586 & $<0.2 \mathrm{mg} / \mathrm{L}$ \\
Iron & & $33.1 \mathrm{mg} / \mathrm{L}$ \\
Magnesium & $4.1 \mu \mathrm{g} / \mathrm{L}$ \\
Manganese & $<10 \mu \mathrm{g} / \mathrm{L}$ \\
Lead & NF T 90-020 & $16.1 \mathrm{mg} / \mathrm{L}$ \\
Potassium & FD T 90-112 & $176.1 \mathrm{mg} / \mathrm{L}$ \\
Sodium & & $0.1 \mathrm{mg} / \mathrm{L}$ \\
Zinc & NF EN ISO 9308-1 & $<1 / 100 \mathrm{~mL}$ \\
\hline Microbial parameters & NF EN ISO 7899-2 & $<1 / 100 \mathrm{~mL}$ \\
E.coli & & $<0.008 \mu \mathrm{g} / \mathrm{L}$ \\
Enterococci & & $<0.008 \mu \mathrm{g} / \mathrm{L}$ \\
\hline Organic micropollutants & & $<0.008 \mu \mathrm{g} / \mathrm{L}$ \\
PAH & & $<0.008 \mu \mathrm{g} / \mathrm{L}$ \\
Fluoranthene & & $<0.008 \mu \mathrm{g} / \mathrm{L} / \mathrm{L}$ \\
Benzo(3,4) fluoranthene & & \\
Benzo(11,12) fluoranthene & & \\
Benzo(1,12) perylene & & \\
Pyrene & & \\
Indéno (1,2,3-cd) pyrène & & \\
Total PAH (6 substances) & & \\
\hline & & \\
\hline & & \\
\hline
\end{tabular}

As the conductivity is also relatively high, about $1400 \mu \mathrm{S} / \mathrm{cm}$, no specific restrictions on the use for irrigation could be required. In fact, as demonstrated by years of research, the ratio of salinity to sodicity (SAR) determines the effects of salts and sodium on soils. Salinity promotes soil flocculation and sodicity promotes soil dispersion. As the values of both salinity and sodicity are moderate, no effect on infiltration rate can be expected from the irrigation with this recycled water. Other factors such as climate, soil type, crop and plant species and management practices also need to be accounted for when determining the acceptable levels of salinity and sodicity of irrigation water. In the case of Bora Bora, the soil has a high permeability, as constituted predominantly of calcareous sand. 
The dominant toxic ion is chloride with a concentration of $271 \mathrm{mg} / \mathrm{L}$, which can cause foliar damage to sensitive plants. Bicarbonate content is also relatively high, $223 \mathrm{mg} / \mathrm{L}$, with a risk of carbonate precipitation during sprinkling. The monitored trace elements are below the recommended maximum concentration limits in irrigation water.

Compared to some decorative plants, the turf grass used in the island is characterized by high salinity tolerance. During the 5-year period of use of recycled water for sprinkler irrigation, no negative impacts on vegetation and turf grass were reported.

The most important requirement of the end users was the reliability of supply of recycled water 24/24 h. Consequently, specific operating and maintenance procedures have been implemented to achieve $100 \%$ reliability of the operation of the recycling facility.

Figure 4. Evolution of normalized membrane permeability (minimum and maximum daily average).

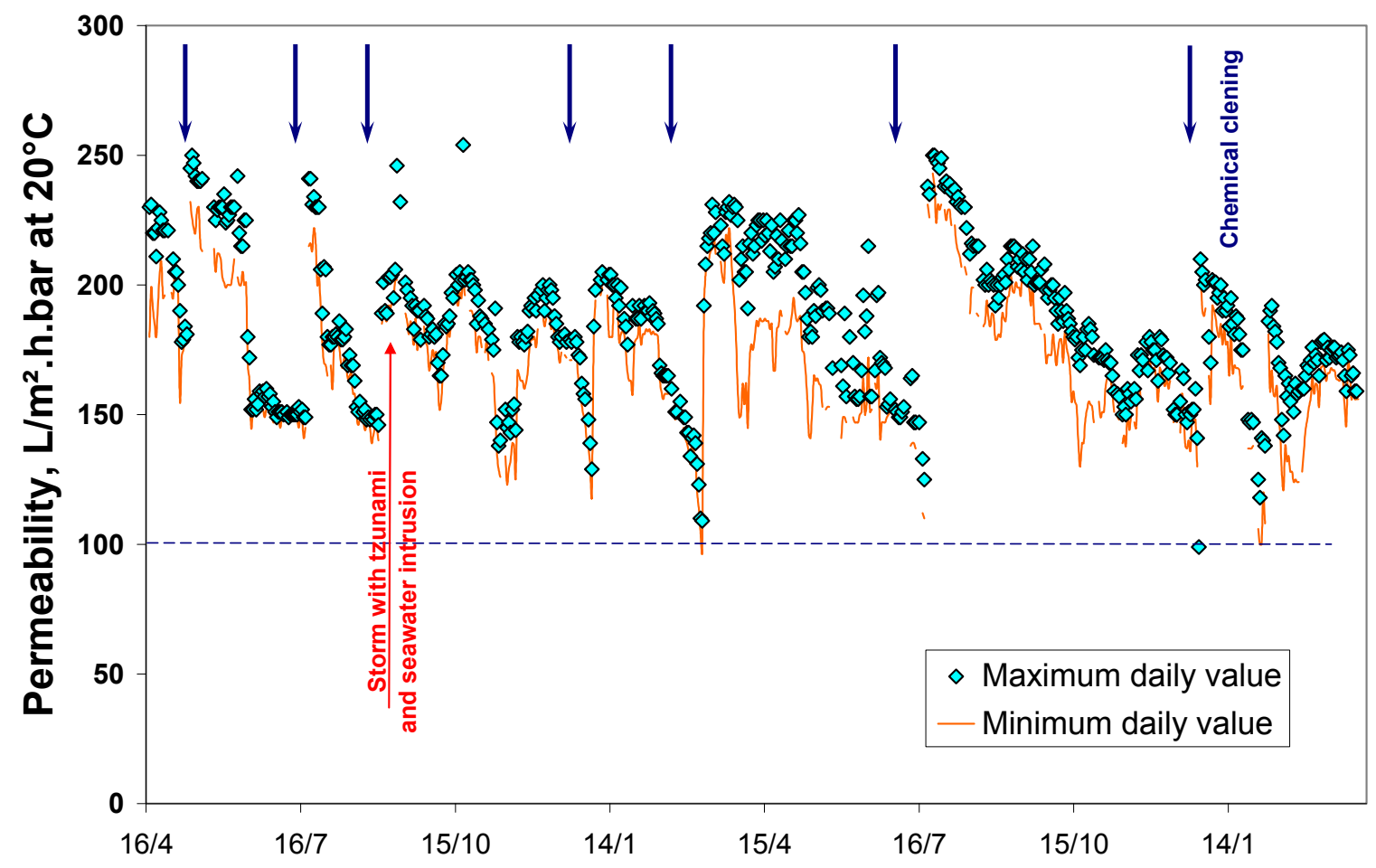

Figure 4 illustrates the evolution of the permeability of submerged ultrafiltration membranes in Bora Bora for the investigated period. Applying the recommended maintenance and cleaning procedures, a good recovery of membrane permeability was observed, 202 to $247 \mathrm{~L} / \mathrm{h} \cdot \mathrm{m}^{2}$ bar at $20{ }^{\circ} \mathrm{C}$ compared to the initial value of $250 \mathrm{~L} / \mathrm{h} \cdot \mathrm{m}^{2}$ bar. It is important to underline that despite some minor operational failures and a major damage of the wastewater treatment plant in September 2005, due to a tsunami with seawater intrusion and loss of activated sludge from the clarifier, an excellent membrane flux was consistently maintained at $24 \pm 2 \mathrm{~L} / \mathrm{h} \cdot \mathrm{m}^{2}$ at $20^{\circ} \mathrm{C}$.

Preventive measures against membrane fouling are the crucial factor to avoid excessive loss of membrane permeability (on-line cleaning using scouring air, backpulses, membrane relax, automated maintenance cleaning). The frequency of chemical recovery cleaning varied from 2 to 6 months depending on the wastewater quality. By safety, the recovery cleaning was carried out before reaching the lower limit value of the permeability, which was fixed at $100 \mathrm{~L} / \mathrm{h} \cdot \mathrm{m}^{2}$ bar. 


\subsection{Water Reuse Applications and Evolution of Recycled Water Demand}

The adequate choice of the treatment technology and the ability to provide high-quality recycled water without any interruption were the two key factors that ensured the fast growth in recycled water demand (Figure 5). A twofold increase in the recycled water consumption was observed shortly after the start-up of the new recycling facility, with an average annual volume of about $70,000 \mathrm{~m}^{3} / \mathrm{yr}$. The number of end users in early 2006 tripled compared to that in 2004.

Figure 5. Evolution of the recycled water demand in Bora Bora.

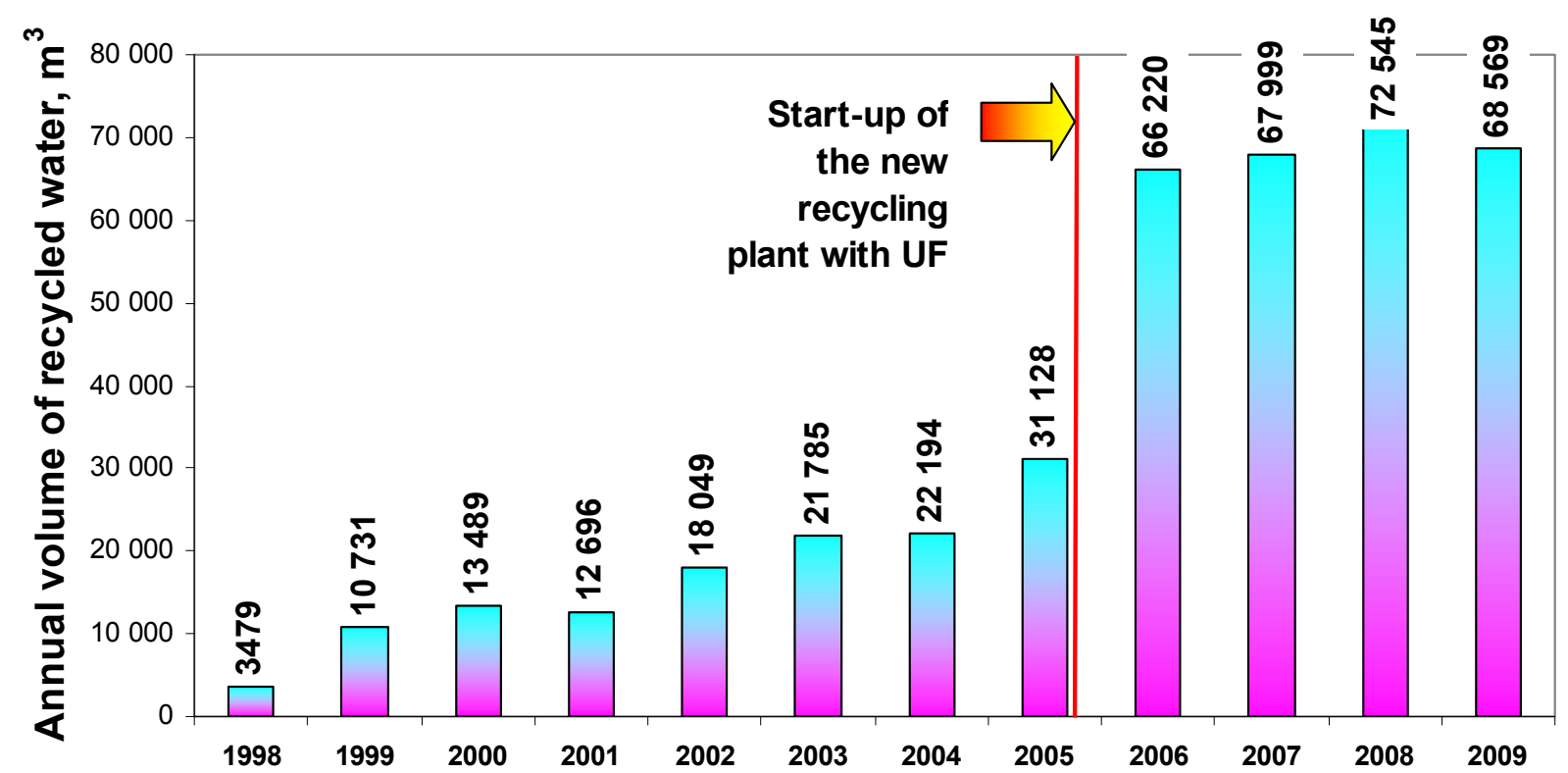

Large consumers are primarily the luxury hotels with landscape irrigation as the major use of recycled water (Figure 6). For 8 of these located on "motu" (small coral islands), the connections were achieved by means of underwater drains ( 0.5 to $2 \mathrm{~km}$, maximum depth $40 \mathrm{~m})$.

Figure 6. View of "motus" and the construction of the distribution network.
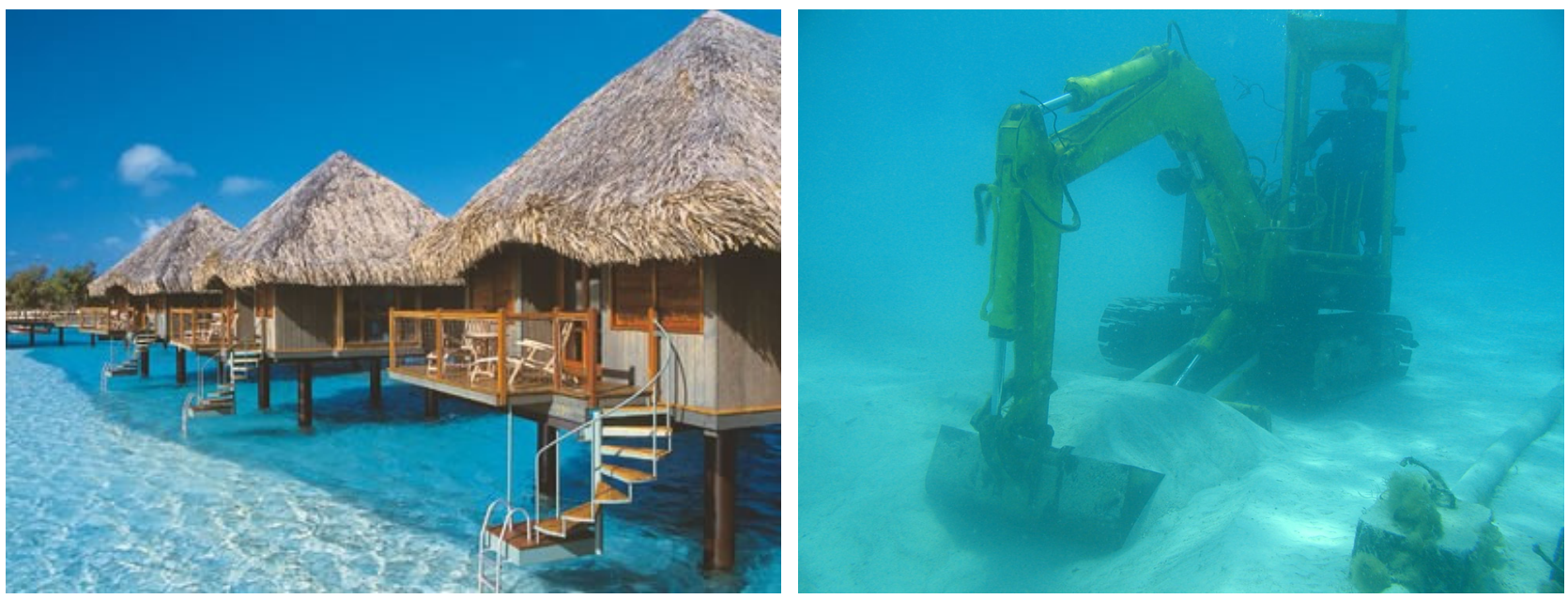

The growth in recycled water demand was associated with the development of other urban uses than the traditional landscape irrigation: 
- Cleaning and landscape irrigation in all water and wastewater plants and pumping stations.

- Boat washing.

- Filling of fire protection boats.

- Washing of construction engines and concrete preparation and tests at over 7 building sites.

Currently, new satellites recycling facilities are under development for golf course irrigation and aquifer recharge.

\subsection{Socio-Economic Aspects and Benefits of Water Reuse}

Capital costs were covered by governmental subsidies, loans and a public-private partnership. The operating and maintenance costs are about $38 \%$ of the life costs. The main component of operating costs is labor, accounting for $46 \%$ of total operation costs, followed by repair and maintenance, $21 \%$. The cost of spare parts and scouring equipment is relatively high because the remoteness of this island, and thus, the high transportation costs. Chemical costs for membrane cleaning and final chlorination contribute to another $12 \%$ of operating costs. Despite the very high price of electricity $(0.18 € / \mathrm{kWh})$ in this isolated tourist island, the contribution of energy costs is only $14 \%$, a relatively low percentage.

The average energy consumption at nominal flow is estimated at $0.36 \mathrm{kWh} / \mathrm{m}^{3}$ with a twofold increase to $0.62 \mathrm{kWh} / \mathrm{m}^{3}$ when hydraulic load drops to $50 \%$ (Figure 7). During operation with flow rates below $30 \%$, the energy consumption raises to $1.0-1.6 \mathrm{kWh} / \mathrm{m} 3$ due to the high fixed energy needs of membrane treatment.

Figure 7. Correlation between the specific energy consumption and the hydraulic flow rate.

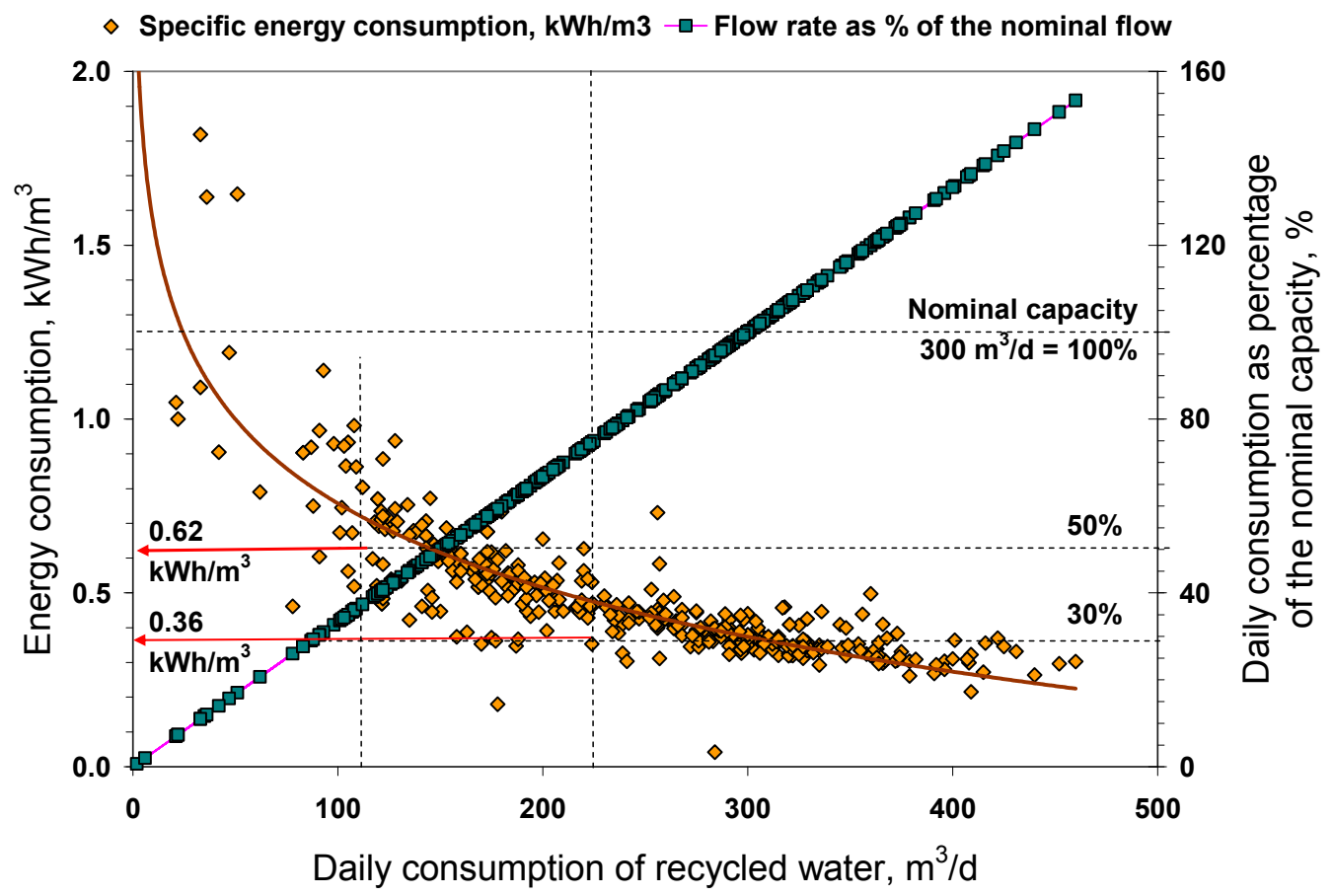

Large users, i.e., the luxury hotels, were the first to recognize the economic benefits of water reuse as the cost of high-quality recycled water was, in fact, 2.5 to 3 times less expensive than potable water. Consequently, recycled water demand increased, encouraged further by an appealing pricing policy. 
In the case of Bora Bora, pricing decision was a crucial factor for the success and economic viability of the water reuse project. As underlined in previous studies [11], recycled water price must reflect the end-users' willingness to pay and the reliability of recycled water supply. The municipality of Bora Bora selected a declining block rate, considered as the most appropriate pricing instrument to achieve economies in delivery costs and attract large water-consumers while providing lower charges for small private users (Table 3).

Table 3. User fees for recycled water in Bora Bora.

\begin{tabular}{|c|c|c|c|c|}
\hline Parameter & Criteria & First block & Second block & Third block \\
\hline Volume for large users, $\mathrm{m}^{3} /$ month & \multirow{2}{*}{$>350 \mathrm{~m}^{3}$} & $<550$ & $550-800$ & $>800$ \\
\hline Recycled water charge, $€ / \mathrm{m}^{3}$ & & 2.35 & 2.18 & 1.65 \\
\hline Volume for medium users, $\mathrm{m}^{3} /$ month & \multirow{2}{*}{$<350 \mathrm{~m}^{3}$} & $<110$ & $110-200$ & $>200$ \\
\hline Recycled water charge, $€ / \mathrm{m}^{3}$ & & 1.16 & 1.08 & 0.88 \\
\hline Volume for small users, $\mathrm{m}^{3} /$ month & \multirow{2}{*}{$<30 \mathrm{~m}^{3}$} & $<5$ & $5-10$ & $>10$ \\
\hline Recycled water charge, $€ / \mathrm{m}^{3}$ & & 0.76 & 0.71 & 0.67 \\
\hline
\end{tabular}

According to this new recycled water pricing established in November 2005, recycled water charges vary from 30 to $100 \%$ of the potable water rate, depending on the user category in terms of water demand. In addition to these consumption-based rates, a fixed annual charge of $187 €$ is required for each connection. In comparison, the previous recycled water charge for polished secondary effluent (not allowed for spray irrigation and other urban uses) was fixed at $0.67 € / \mathrm{m}^{3}$ regardless of water consumption.

The adequate pricing of recycled water ensured the economic viability of water reuse. This enabled to cover the operating and maintenance costs of tertiary treatment, pumping and distribution network.

In addition to economic benefits to large end-users, another important benefit was the avoided revenue losses of private building and tourist companies during drought periods. In fact, because of severe drought at the end of 2005, the use of drinking water for non-potable purposes was proscribed and four important building sites were to be interrupted because of the lack of water for concrete preparation and tests, as well as for landscaping. The economic damage that has been caused by the delay of construction was estimated at 2 to 3 million $€$. This does not take into account the potential loss of revenue during the peak tourist season that would have been over 50 million $€$.

The economic and social benefits of the new recycling scheme were also recognized by the local public authorities. The start-up of the membrane facility enabled not only to postpone the construction of an additional desalination plant, but also to limit frequent and unavoidable water supply interruptions for the local residents during drought periods.

Finally, the principal environmental benefit of the reuse of well-treated wastewater was the protection of local natural freshwater resources with an estimated saving of $10 \%$ of drinking water for domestic potable uses. Another important environmental benefit is the reduction of wastewater discharge, contributing to the safeguard of the lagoon and its biodiversity.

An important factor for the appreciation and recognition of economic viability and water reuse benefits is strong community involvement, political support and active collaboration between stakeholders (decision-makers, legislative officers, operators, end-users, local residents). 
Public education program was an essential part of the water reuse project. Periodic forums have been organized with the municipality, legislative officers, consultants, operators, local entities, end users and public representatives to present the membrane technology, water quality and health aspects, as well as to assess economic and environmental benefits of water reuse (Figure 8).

Figure 8. View of public forums organized at the water recycling plant.

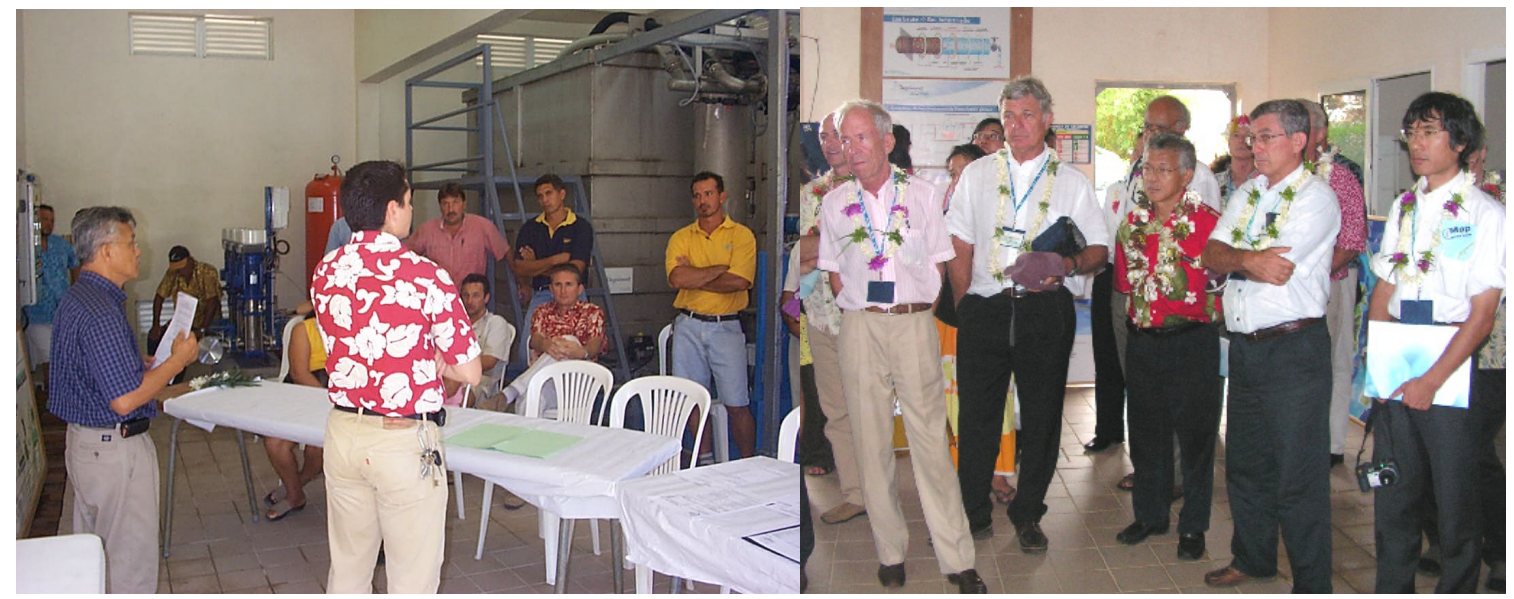

Currently, several new water reuse projects with an extension of the existing recycling facility are under consideration:

- Extension of the fire protection network and construction of a new fire reservoir,

- Construction of a new membrane recycling facility with the production of high-quality recycled water for golf course irrigation (150 ha) and aquifer recharge (UF/RO treatment facility).

\section{Conclusions}

The urban water reuse project in Bora Bora is a good example of the successful implementation of urban water reuse and its role in integrated water resource management. The main driving forces of this project were water shortage, increased population with the development of tourist activity and more frequent droughts related to climate change. The major key to success was the consideration, from the beginning of project development, of all the aspects of water reuse, including the technical challenges, economic viability and environmental and social benefits.

The technical challenge of the uninterrupted supply of high-quality recycled water was resolved by the implementation of membrane technology and an appropriate water quality monitoring. The economic viability of the project was ensured by adopting a pricing policy which would cover operating and maintenance costs of the water recycling scheme, including pumping and distribution network. The adopted pricing strategy favored the increase in recycled water demand and thus, a better cost recovery. It was clearly shown that water recycling allows maintaining a number of economic activities such as construction, boat cleaning and pleasant landscape in conditions of severe droughts with strong restrictions on potable water consumption for non-potable uses.

One of the well recognized economic benefits was the prevention of revenue loss of building and tourist companies during the severe drought at the end of 2005. The use of drinking water for non-potable purposes was proscribed during this period of drought and four important building sites 
were to be interrupted because of the lack of water for concrete preparation and tests, as well as for landscaping.

The close involvement of local authorities, water professionals and stakeholders have made it possible to recognize the economic viability of water recycling and to identify several advantages and benefits, including the preservation of the outstanding environment of this small island and the release of an equivalent volume of potable water for domestic purposes, local economic development, and a reliable water supply for the population during droughts. It was estimated that the water recycling program enabled saving $10 \%$ of the precious natural freshwater resources.

The strong effort of the community of Bora Bora for integrated water resource management has been recognized since 2000 by being awarded the "Blue Flag of Europe", a symbol of its exemplary environmental commitment.

\section{Acknowledgments}

The authors acknowledge the municipality of Bora Bora for their support and active involvement, as well as the precious contribution of the managers and operators of the wastewater treatment and the recycling facility. A part of this work was presented at the 7th IWA Water Reuse Conference in Brisbane in 2009 and was published in the conference proceedings.

\section{References}

1. Funamizu, N.; Onitsuka, T.; Hatori, S. Water reuse in Japan. In Water Reuse: An International Survey of Current Practice, Issues and Needs, 1st ed.; Jimenez, B., Asano, T., Eds.; IWA Publishing: London, UK, 2008; pp. 373-386.

2. Asano, T.; Burton, F.J.; Leverenz, H.L.; Tsuchihashi, R.; Tchobanoglous, G. Water Reuse: Issues, Technology, and Applications, 1st ed.; McGraw-Hill Professional Publishing: New York, NY, USA, 2007; pp. 915-918, 1453-1459.

3. Law, I.B. Rouse Hills-Australia's first full-scale domestic non-potable reuse application. Water Sci. Tech. 1996, 33, 71-78.

4. Radcliffe, J.C. Water Recycling in Australian; Australian Academy of Technological Sciences and Engineering: Parkville, Australia, 2004; pp. 53-59.

5. Willis, R.M.; Stewart, R.A.; Williams, P.R.; Hacker, C.H.; Emmonds, S.C.; Capati, G. Residential potable and recycled water end uses in a dual reticulated supply system. Desalination 2011, 272, 201-211.

6. Sala, L. Integration of water reuse in the management of water resources in Costa Brava (Girona, Spain). In Milestones in Water Reuse: The Best Success Stories, 1st ed.; IWA Publishing: London, UK, 2011, in press.

7. Lazarova, V.; Hills, S.; Birks, R. Using recycled water for non potable urban uses: A review with particular reference to toilet flushing. Water Supply 2003, 3, 69-77.

8. Lazarova, V.; Brissaud, F. Intérêt, bénéfices et contraintes de la réutilisation des eaux usées en France. L'eau, l'industrie, les nuisances 2007, 299, 43-53. 
9. Anderson, J.; Baggett, S.; Jeffrey, P.; McPherson, L.; Marks, J.; Rosenblum, E. Public acceptance of water reuse. In Water Reuse: An International Survey of Current Practice, Issues and Needs, 1st ed.; Jimenez, B, Asano, T., Eds.; IWA Publishing: London, UK, 2008; pp. 332-350.

10. Lazarova, V; Bahri, A. Irrigation with Recycled Water: Agriculture, Turfgrass and Landscape; CRC Press: Boca Raton, FL, USA, 2005.

11. Morris, J.; Lazarova, V.; Tyrrel, S.. Economics of water recycling for irrigation. In Irrigation with Recycled Water: Agriculture, Turfgrass and Landscape; Lazarova, V., Bahri, A., Eds.; CRC Press: Boca Raton, FL, USA, 2005; pp. 266-283.

(C) 2012 by the authors; licensee MDPI, Basel, Switzerland. This article is an open access article distributed under the terms and conditions of the Creative Commons Attribution license (http://creativecommons.org/licenses/by/3.0/). 